\title{
PETROLOGICAL, MINERALOGICAL AND GEOCHEMICAL DATA FROM THE EOHELLENIC OPHIOLITIC NAPPE IN THE ISLAND OF SKYROS, GREECE
}

\author{
Karkalis C. ${ }^{1}$, Magganas A. ${ }^{1}$ and Koutsovitis P. ${ }^{2}$ \\ ${ }^{I}$ Faculty of Geology and Geoenvironment, National \& Kapodistrian University of Athens. \\ Panepistimioupolis, Athens, GR-15784
}

${ }^{2}$ IGME, $1^{\text {st }}$ Spirou Louis St., Olympic Village, Acharnae, GR, 13677, chriskarkalis@gmail.com, amagganas@geol.uoa.gr,petroskoutsovitis@yahoo.com

\begin{abstract}
The ophiolite of Skyros mainly consists of serpentinized harzburgites, gabbroic rocks, dolerites, tholeiitic basaltic lavas, rodingites, as well as ophicalcites. This ophiolitic sequence comprises of an ophiolitic mélange of pre-Upper Cretaceous age belonging to the Eohellenic nappe, has been affected by low to moderate metamorphic and metasomatic processes. Their mineral chemistry as well as their whole rock chemistry suggests that these ophiolitic rocks are associated with supra-subduction related processes. The presence of vesuvianite crystals in rodingites, as well as the occurrence of relict spinels within serpentinitic rocks, further confirms this assumption. Geochemical and petrological comparison between Skyros ophiolitic rocks and similar rocks of the Eohellenic nappe in East Thessaly and other $N$. Sporades islands, reveal that they all share many petrogenetical features. These eastcentral Greece Eohellenic ophiolites, and the ophiolitic rocks of the upper tectonic unit of the Attico-Cycladic Zone may possibly form an elongated ophiolitic zone associated to the hanging wall of the North Cycladic Detachment System.

Keywords: Metasomatism, metamorphism, vesuvianite, rodingite, subduction.
\end{abstract}

\section{Пврі́ $\lambda \psi \eta$}

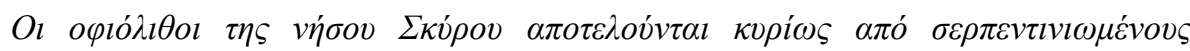

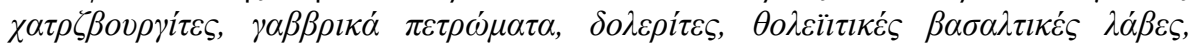

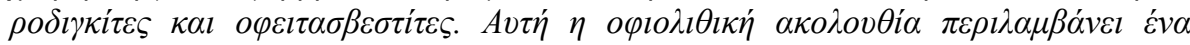

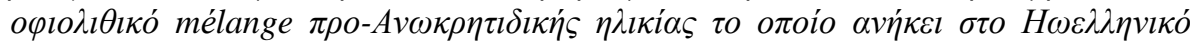
Kád

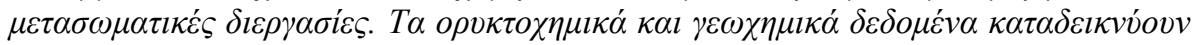

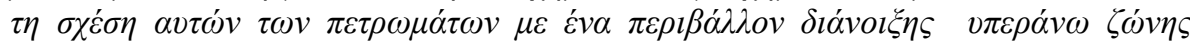

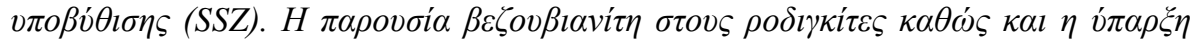

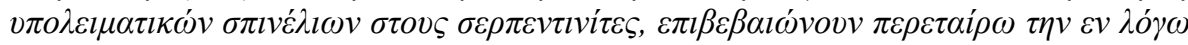

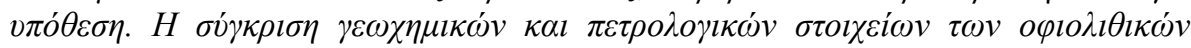

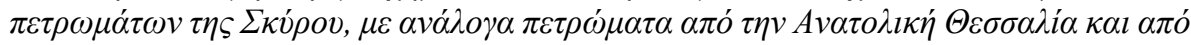

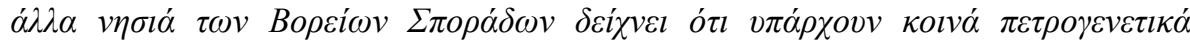

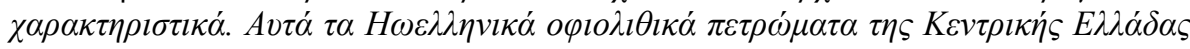

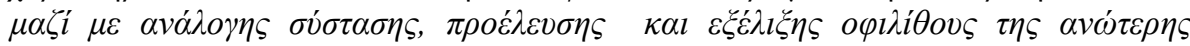

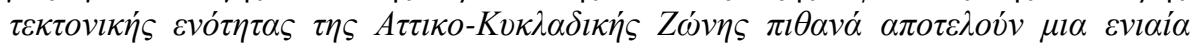




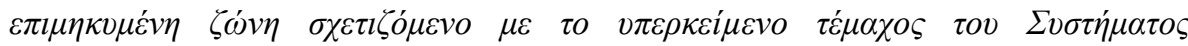

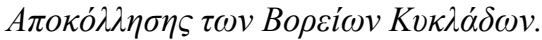

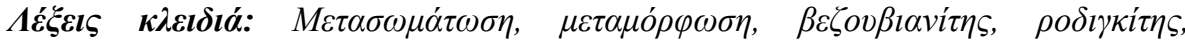
$v \pi \circ \beta \dot{v} \theta \imath \sigma \eta$.
\end{abstract}

\title{
1. Introduction
}

Jurassic ophiolites in Greece are mostly exposed in its Central and Northern parts forming two subparallel zones which trend NNW-SSE (Stampfli et al., 2003; Robertson, 2004; Papanikolaou, 2009; Ferrière et al., 2012). Ophiolitic rocks, independently of zone of their occurrence, show as prevailing petrological and geochemical characters either those related to a subduction setting or those of a ridge one. For example, the ophiolitic sequences of Pindos, Koziakas and West Othris present mostly MORB and back-arc basin (BAB) affinities (e.g. Pomonis et al., 2007; Pelletier et al., 2008; Whattam and Stern, 2011), whereas the ophiolitic sequences of East Othris, Vourinos, Rhodiani and Evros are supra-subduction zone (SSZ) ophiolites (Beccaluva et al., 1984; Magganas, 2002; Saccani et al., 2008; Magganas and Koutsovitis, 2015). The Skyros ophiolitic rocks, occurring within the eastern zone and along with schists, phyllites and marbles, are part of the Eohellenic tectonic nappe (Harder et al., 1983).

Here we present our initial results from evaluation of new petrographical, mineralogical and wholerock major and trace chemical element data of the main magmatic rock types of the Skyros ophiolite in order to contribute to the gap existing in their petrologic knowledge and in general on the geology of the Eohellenic nappe (Fig. 1), which is also exposed in other islands of North Sporades as well as in Eastern Thessaly and Central Macedonia regions. Moreover, our conclusions may provide constrains on the development and closure of the Mesozoic Tethyan oceanic and continental strands that these ophiolitic rocks were formed and emplaced, as well as on their petrogenetic processes and metasomatic/metamorphic evolution.

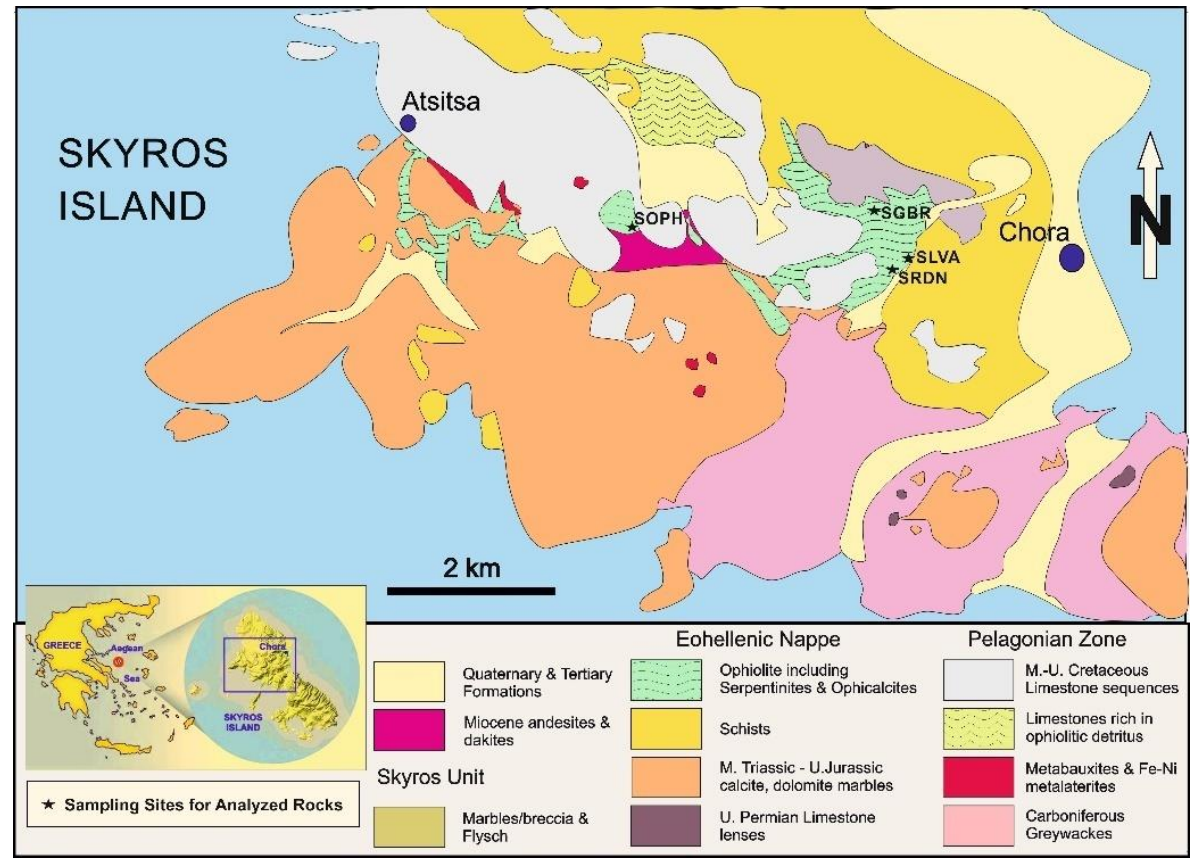




\section{Geological Setting}

Skyros Island is located in the central Aegean Sea and belongs to the group of North Sporades islands (Fig. 1). It consists of the Pelagonian Zone (mostly metamorphosed sedimentary rocks), the Eohellenic tectonic nappe and the Skyros Unit (consisting of marbles and breccia with flyschoid members). The Pelagonian Zone is regarded as being part of the Internal Hellenides and is distinguished into two distinct metamorphic and non-metamorphic parts (Katsikatsos, 1992; Papanikolaou, 2009). In Skyros Island, the Pelagonian Zone is located mostly in the southern and north-western region.

The Eohellenic nappe was emplaced during the Late Jurassic to Early Cretaceous overthrusting Palaeozoic-Middle Jurassic Pelagonian basement rocks, and in Skyros it mainly consists of an ophiolitic mélange (Katsikatsos, 1992; Pe-Piper and Piper, 2002). This ophiolitic formation is mostly located in the central and eastern parts of the island and to a lesser extent in the western part. The Skyros ophiolite includes massive or highly deformed serpentinite, which locally in its margin change to talc schist or in other places intruded by rodingitic dykes, massive gabbroic rocks, dolerite dykes intruded by quartz and epidote rich veins, massive lavas of basaltic composition and ophicalcite. According to Pe-Piper and Piper (2002) K-Ar dating on a gabbroic rock (diorite) of the ophiolitic formation located at mountain Notos, yields for the Skyros ophiolite a Lower Cretaceous age $(125 \pm 8 \mathrm{Ma})$. In contact to ophiolitic rocks thin slices of massive or brecciated deep sea cherts of red colour rarely occur. As the Skyros ophiolitic rocks are usually found in a chaotic mixture they constitute an ophiolitic melange. This melange is usually found above a volcano-sedimentary metamorphosed sequence which includes marbles, calc- and mica-schists, phyllites, metagreywacke and blueschists (Harder et al., 1983; Baltatzis, 1984; Katsikatsos, 1992). On top of some serpentinite erosion surfaces dark brown Fe-rich lateritic horizons cover by transgressive Upper Cretaceous, usually rudist bearing, limestones, also occur. The Skyros Unit, which consists of coarse grained marbles, breccia and flysch, is emplaced above the Eohellenic tectonic nappe (Jacobshagen and Matarangas, 2004).

In eastern Thessaly, the Eohellenic Nappe is metamorphosed and was emplaced during Upper Jurassic to Lower Cretaceous, overthrusting the pre-upper Cretaceous Pelagonian zone rocks (Migiros, 1986). The ultrabasic rocks of the Eohellenic nappe in eastern Thessaly are mainly serpentinized hartzburgites, with serpentinized dunite bodies in the uppermost parts which contain small tectonized and broken chromite lenses (Migiros and Economou, 1988). In the North Sporades islands such as Skiathos (Heinitz and Heinitz-Richter, 1983) and Skopelos (Matarangas, 1992), the main tectono-stratigraphic units include the Pelagonian unit, Eohellenic nappe relics and the Mesoautochthonous complex (Jacobshagen and Matarangas, 2004). In Alonnisos island, the Eohellenic nappe also overthrusts the Pelagonian unit, whereas in Kyra Panagia the basaltic andesites seem to also be part of the Eohellenic nappe (Pe-Piper et al., 1996).

\section{Sampling and analytical methods}

Samples were collected from Northern part of Skyros and more specifically from areas between the Skyros town and the Atsitsa village. Twelve samples were collected and petrographically studied. These include four serpentinites (samples SOPH, SSRP, SRPD, SDUN), one ophicalcite (sample SOPH2), one rodingite (sample SRDN), two lavas (samples SLVA, SLVA2) three dolerites (samples SMLE, SMLE2, SMLE3) and one gabbro (SGBR). Mineral chemistry analyses were conducted in two basaltic lavas (samples SLVA, SLVA2), one rodingite (sample SRDN), one serpentinite (sample SOPH), and one gabbro (sample SGBR).

Whole-rock analyses (Table 1) were carried out at Acme Analytical Laboratories in Canada with the use of ICP-MS 4A-4B for major elements, trace elements and REE and included one lava, one dolerite, one rodingite and one serpentinite sample. Low Detection Limits range from $0.002 \%$ to $0.04 \%$ and High Detection Limits are all 100\% for major oxides. The Low Detection Limits range 
from $0.5 \mathrm{ppb}$ to $20 \mathrm{ppm}$ and the High Detection Limits range from $50 \mathrm{ppm}$ to $50000 \mathrm{ppm}$ for the trace elements. For REE the Low Detection Limits range from $0.01 \mathrm{ppm}$ to $30 \mathrm{ppm}$ and the High Detection Limits range from $50000 \mathrm{ppm}$ to $10000 \mathrm{ppm}$. Mineral chemistry analyses (Table 2) were obtained using a SEM JEOL JSM-5600 equipped with an Oxford LinkISIS 300EDX microanalysis system, at the University of Athens, Department of Mineralogy and Petrology.

\section{Results}

\subsection{Petrography and mineral chemistry}

Serpentinite presents mesh textural features with slip-fiber (Fig. 2a) and cross-fiber chrysotile veins. Their mineral assemblage mainly consists of serpentine (mainly antigorite and few chrysotile) and orthopyroxene bastites, which indicates their harzburgitic origin. A few relict spinels with quite low $\mathrm{Cr} \#$ (38.18-38.87) and moderate $\mathrm{TiO}_{2}(0.14-0.25$ wt.\%) contents, have been identified, while some of them are classified as $\mathrm{Fe}$-chromite with high $\mathrm{Cr} \#$ (92.69) and $\mathrm{FeO}$ (51.88 wt.\%) values and low $\mathrm{MgO}$ (4.45 wt.\%) and $\mathrm{Al}_{2} \mathrm{O}_{3}(1.5$ wt.\%) contents. Secondary minerals include magnetite (Fig. 2b), derived from spinel and olivine alteration, as well as magnesite in veinlets. Ophicalcite also shows mesh texture. It mainly consists of serpentine and calcite, the former sometimes in the form of bastite after orthopyroxene and as chrysotile veinlets. Magnetite also occur. Gabbro is medium grained with secondary quartz veins. It mostly consists of saussuritized plagioclase and amphiboles.
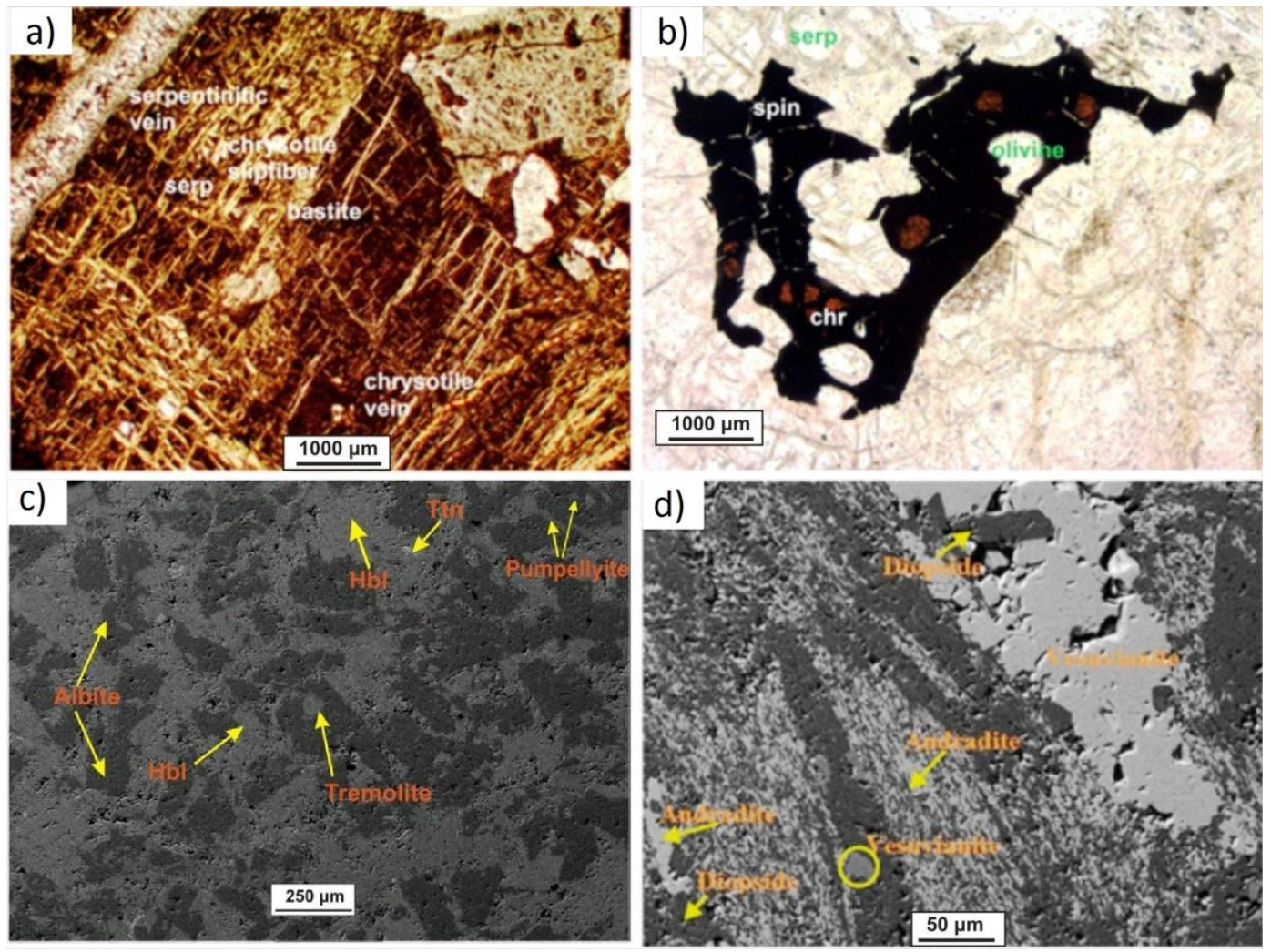

Figure 2 - a. Serpentinite sample (SOPH) including slip-fiber chrysotile and hourglass/mesh antigorite as well as some bastites; b. Serpentinite sample (SOPH) with serpentine surrounding xenomorphic spinel (magnetite with residue olivine) grain and relict chromite patches preserved in the core; $c$. Dolerite sample (SMLE3). Subophitic texture with amphiboles (hornblende and tremolite), albite, titanite and pumpellyite. d. Rodingite sample (SRDN) consisting of diopside, vesuvianite and hydroandradite grains. 
Amphiboles can be separated into two groups. The first group includes hornblende with relatively high $\mathrm{Al}_{2} \mathrm{O}_{3}$ (5.86-5.11wt.\%), $\mathrm{TiO}_{2}$ (1.62-1.52wt.\%) and $\mathrm{Na}_{2} \mathrm{O}$ (1.01-1.09 wt.\%) contents, which possibly indicates a magmatic origin (cf. Koutsovitis, 2012), while the second group includes metamorphic hornblende with lower $\mathrm{Al}_{2} \mathrm{O}_{3}$ (4.43-4.65wt.\%), $\mathrm{TiO}_{2}\left(0.55-0.58\right.$ wt.\%) and $\mathrm{Na}_{2} \mathrm{O}$ (0.62-0.65 wt.\%) contents. Basic plagioclase was not recognized having being replaced by albite. Secondary minerals also include clouded epidote and zoisite. Opaque minerals include Fe-Ti-oxides and hematite.

From the above petrographic and mineral chemistry data, the abundance of hornblende and the absence of any clinopyroxene crystal the original rock can be characterized as hornblende gabbro. The basaltic lava, which shows aphyric, intergranular, intersertal and micro-porphyritic textures, mainly consists of secondary minerals and some few relics of clinopyroxene microphenocrysts. Secondary minerals include almost pure albite (Ab99.7-98.7), Mg-rich chlorites (brunsvigites), epidote, titanite, pumpellyite and quartz as interstitial mass or late veins. On the other hand, dolerites present

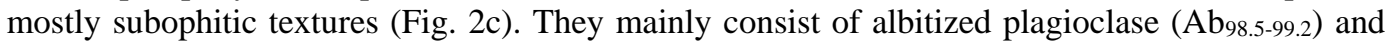
amphiboles, which can be distinguished into hornblende and secondary tremolite and actinolite. Some hornblende and plagioclase can be observed as inclusions in each other, clearly indicating their syncrystallization. Secondary minerals also include epidote, zoisite, titanite, quartz and chlorite. Opaque minerals include Fe-Ti-oxides.

Rodingite sample (Fig. 2d) SRDN consists of hydrogarnets, vesuvianite, chlorite (brunsvigite), diopside and prehnite. Hydrogarnets mostly appear as hydroandradites $\left(\mathrm{Alm}_{0.00} \mathrm{Adr}_{61.33-67.43} \mathrm{Grs}_{28.25}\right.$ $\left.{ }_{35.16} \operatorname{Prp} 0.10-2.49 \mathrm{Sps}_{0.00-0.33} \mathrm{Uv}_{0.41-2.75}\right)$, but there are also accessory uvarovite crystals $\left(\mathrm{Alm}_{0.00} \mathrm{Andr}_{38.94} \mathrm{Grs}_{19.95} \operatorname{Prp}_{1.07} \mathrm{Sps}_{0} \mathrm{Uv}_{40.05}\right)$. The uvarovite Cr-bearing crystals $\left(\mathrm{Cr}_{2} \mathrm{O}_{3}: 10.34\right.$ wt.\%), most likely formed at the expense of spinel. The clinopyroxenes are appearing as diopside grains $\left(\mathrm{En}_{48.53-49.89} \mathrm{Wo}_{47.56-48.10} \mathrm{Fs}_{2.32-3.33} \mathrm{Mg}_{93.96-96.28}\right)$, exhibiting high $\mathrm{Mg} \#$ values (89.71-93.56) and low $\mathrm{TiO}_{2}$ (0.00-0.04 wt. \%), $\mathrm{Al}_{2} \mathrm{O}_{3}\left(0.00-0.61\right.$ wt. \%), $\mathrm{Na}_{2} \mathrm{O}\left(0.00-0.01\right.$ wt. \%) and $\mathrm{Cr}_{2} \mathrm{O}_{3}(0.00-0.06$ wt.\%) values. Vesuvianite presents highly ranging $\mathrm{TiO}_{2}$ values $(0.02-0.59$ wt.\%) while the $\mathrm{MgO}$ range from 2.78 to 3.33 wt. $\%$.

Table 1 - Representative average mineral chemistry analyses.

\begin{tabular}{|c|c|c|c|c|c|c|c|c|c|c|c|c|c|c|c|}
$\begin{array}{c}\text { Rock } \\
\text { Type }\end{array}$ & \multicolumn{3}{|c|}{$\begin{array}{c}\text { Rodingite } \\
\text { Miner. }\end{array}$} & $\begin{array}{c}\text { Serpen-gt } \\
\text { tinite }\end{array}$ & $\begin{array}{c}\text { Basaltic } \\
\text { Lava }\end{array}$ & \multicolumn{4}{|c|}{ Dolerite } & \multicolumn{4}{c|}{ Gabbro } \\
\hline $\mathrm{SiO}_{2}$ & 37.42 & 55.67 & 37.40 & 0.22 & 68.40 & 38.10 & 68.11 & 38.22 & 52.49 & 37.49 & 68.75 & 39.43 & 50.58 & 37.38 \\
\hline $\mathrm{TiO}_{2}$ & 0.14 & 0.05 & 0.23 & 0.20 & 0.08 & 0.08 & 0.02 & 0.11 & 2.81 & 0.01 & 0.16 & 0.05 & 1.21 & 0.05 \\
\hline $\mathrm{Al}_{2} \mathrm{O}_{3}$ & 5.18 & 0.18 & 16.42 & 35.16 & 18.94 & 22.33 & 19.08 & 25.06 & 3.37 & 24.56 & 18.92 & 27.84 & 5.25 & 24.82 \\
\hline $\mathrm{FeO}$ & 18.34 & 0.93 & 3.00 & 15.40 & 0.47 & 13.05 & 0.05 & 9.65 & 11.92 & 2.11 & 0.00 & 6.51 & 10.53 & 2.45 \\
\hline $\mathrm{MnO}$ & 0.29 & 0.12 & 0.09 & 0.12 & 0.03 & 0.36 & 0.00 & 0.12 & 0.25 & 0.09 & 0.14 & 0.00 & 0.14 & 0.10 \\
\hline $\mathrm{MgO}$ & 0.17 & 10.78 & 3.07 & 15.25 & 0.00 & 0.00 & 0.00 & 0.00 & 16.77 & 3.37 & 0.00 & 0.00 & 16.90 & 2.95 \\
\hline $\mathrm{CaO}$ & 32.37 & 14.56 & 34.56 & 0.00 & 0.12 & 23.05 & 0.22 & 23.17 & 10.99 & 22.40 & 0.03 & 23.40 & 11.09 & 22.72 \\
\hline $\mathrm{Na}_{2} \mathrm{O}$ & 0.00 & 0.00 & 0.51 & 0.00 & 10.79 & 0.01 & 11.03 & 0.10 & 0.57 & 0.09 & 10.99 & 0.03 & 0.33 & 0.03 \\
\hline $\mathrm{K}_{2} \mathrm{O}$ & 0.00 & 0.00 & 0.12 & 0.00 & 0.04 & 0.03 & 0.01 & 0.01 & 0.10 & 0.10 & 0.00 & 0.14 & 0.18 & 0.09 \\
\hline $\mathrm{Cr}_{2} \mathrm{O}_{3}$ & 2.36 & 0.03 & 0.12 & 32.86 & 0.02 & 0.00 & 0.05 & 0.00 & 0.12 & 0.11 & 0.07 & 0.00 & 0.20 & 0.04 \\
\hline $\mathrm{NiO}^{2}$ & 0.02 & 0.00 & 0.47 & 0.00 & 0.00 & 0.00 & 0.00 & 0.00 & 0.01 & 0.09 & 0.00 & 0.00 & 0.09 & 0.00 \\
\hline $\mathrm{Total}_{2}$ & 96.06 & 100.02 & 95.20 & 99.20 & 98.88 & 96.82 & 98.60 & 96.92 & 97.37 & 90.44 & 99.0697 .38 & 97.08 & 90.62 \\
\hline
\end{tabular}

\subsection{Whole Rock Chemistry}

For classification of the basic rocks, due to their high percentage of secondary minerals and LOI values, we base mostly on relatively immobile elements diagrams. So, using the plot of $\mathrm{Zr} / \mathrm{Ti}$ vs. Nb/Y (Fig. 3a) both lava and gabbro samples plot within the basaltic field, indicating secondary silicification of the rocks. In addition, both of these studied rocks plot in the tholeiitic field (Fig. 3b). From REE/MORB 
normalized patterns the tholeiitic basalt exhibits a slight fractionation between the LREE and HREE, however all REE values being constantly near MORB ones. The gabbro presents moderate to low LREE values, slightly higher MREE and even higher HREE patterns (Fig. 4a). The (La/Yb) MORB-N values are quite similar for the basalt and gabbro (1.22 and 1.4 respectively), with the basalt exhibiting lower (La/Sm) MORB-N values compared to gabbro (1.36 and 2.41 respectively) (Fig. 4a), while the Eu anomalies vary from negative to slightly positive $\left(\mathrm{Eu}_{N} / \mathrm{Eu}^{*}=1.03\right.$ and 0.76 respectively). Diorite from Skyros Island (Pe-Piper and Piper, 2002) presents subparallel LREE patterns with basalt and gabbro respectively (Fig. 4a). Its MORB normalized multi-trace element pattern is almost identical with Skyros gabbro (Fig. 4b) suggesting a same source of the rocks. The MORB normalized multi-trace element of the gabbro and lava samples show that the normalized Th and $U$ values are much higher compared to those of $\mathrm{Nb}$. Both samples have noticeable positive $\mathrm{Sr}$ and $\mathrm{Pb}$ anomalies, as well as slight negative $\mathrm{Zr}$ anomalies (Fig. 4b). Low Ti tholeiitic volcanic rocks from Kyra Panagia and Alonnisos ophiolites (Pe-Piper et al., 1996) exhibit high U, Th and K values, while their Sr positive anomaly is also observed in basalt, gabbro and diorite samples (Fig. 4b).

Table 2 - Whole Rock major (wt.\%) and trace element (ppm) compositions of serpentinite (SOPH), rondigite (SRDN), gabbro (SGBR) and lava (SLVA), -: below detection limit.

\begin{tabular}{|c|c|c|c|c|c|c|c|c|c|}
\hline $\mathrm{SiO}_{2}$ & 39.66 & 43.49 & 50.37 & 56.76 & $\mathrm{La}$ & 0.3 & 20.2 & 1.4 & 1.8 \\
\hline $\mathrm{TiO}_{2}$ & 0.01 & 0.04 & 0.23 & 0.93 & $\mathrm{Ce}$ & 0.3 & 43 & 2.3 & 4.4 \\
\hline $\mathrm{Al}_{2} \mathrm{O}_{3}$ & 1.39 & 9.43 & 17.06 & 15 & $\operatorname{Pr}$ & - & 4.64 & 0.34 & 0.73 \\
\hline $\mathrm{Fe}_{2} \mathrm{O}_{3}$ & 8.39 & 3.45 & 5.67 & 11.98 & $\mathrm{Nd}$ & - & 16 & 1.4 & 4.1 \\
\hline MnO & 0.11 & 0.16 & 0.11 & 0.15 & $\mathrm{Sm}$ & - & 3.49 & 0.61 & 1.39 \\
\hline MgO & 34.79 & 10.2 & 9 & 3.04 & $\mathrm{Eu}$ & - & 0.45 & 0.21 & 0.63 \\
\hline $\mathrm{CaO}$ & 0.44 & 29.59 & 9.98 & 5.81 & $\mathrm{Gd}$ & - & 4.27 & 1.13 & 2.48 \\
\hline $\mathrm{Na}_{2} \mathrm{O}$ & 0.02 & - & 2.8 & 2.47 & $\mathrm{~Tb}$ & - & 0.76 & 0.22 & 0.43 \\
\hline $\mathrm{K}_{2} \mathrm{O}$ & 0.01 & - & 0.81 & 0.01 & Dy & - & 5.32 & 1.61 & 3.6 \\
\hline $\mathrm{P}_{2} \mathrm{O}_{5}$ & - & 0.04 & 0.02 & 0.07 & Ho & - & 1.04 & 0.37 & 0.69 \\
\hline $\mathrm{Cr}_{2} \mathrm{O}_{3}$ & 0.462 & 0.027 & 0.076 & - & $\mathrm{Er}$ & 0.04 & 3.62 & 1.2 & 2.41 \\
\hline LOI & 14.4 & 3.4 & 3.8 & 3.7 & $\mathrm{Tm}$ & - & 0.48 & 0.18 & 0.3 \\
\hline TOT/C & 0.11 & 0.18 & 0.03 & 0.02 & $\mathrm{Yb}$ & 0.08 & 2.87 & 1.22 & 1.8 \\
\hline TOT/S & 0.06 & - & - & - & $\mathrm{Lu}$ & 0.02 & 0.45 & 0.17 & 0.3 \\
\hline TOTAL & 99.85 & 100.01 & 99.96 & 99.94 & Mo & - & - & - & - \\
\hline $\mathbf{B a}$ & 5 & 5 & 34 & 7 & $\mathrm{Cu}$ & 7.7 & 200.1 & 15.2 & 20.7 \\
\hline $\mathbf{B e}$ & - & 5 & - & - & $\mathrm{Pb}$ & 1 & 2.1 & 1.4 & 2.2 \\
\hline Co & 111.5 & 23.9 & 30.7 & 26.2 & $\mathrm{Zn}$ & 16 & 7 & 7 & 73 \\
\hline Cs & - & - & 0.2 & - & $\mathrm{Ni}$ & 2458.5 & 124.4 & 111.1 & 18.5 \\
\hline $\mathbf{G a}$ & - & 3.8 & 8.5 & 12.2 & As & 0.8 & 0.5 & 2.3 & 0.6 \\
\hline Hf & - & 2.9 & 0.5 & 1.2 & $\mathrm{Cd}$ & - & 0.3 & - & - \\
\hline $\mathrm{Nb}$ & - & 17.8 & 0.1 & 0.3 & $\mathrm{Sb}$ & - & - & - & - \\
\hline $\mathbf{R b}$ & 0.1 & - & 11 & - & $\mathrm{Bi}$ & - & - & - & - \\
\hline Sn & - & - & - & 1 & $\mathrm{Ag}$ & - & - & - & - \\
\hline $\mathbf{S r}$ & 3.5 & 17.6 & 193 & 236.5 & $\mathrm{Au}$ & 1.3 & 11.7 & - & - \\
\hline $\mathbf{T a}$ & - & 1.2 & - & - & $\mathrm{Hg}$ & 0.11 & 0.09 & 0.12 & 0.08 \\
\hline Th & - & 8.2 & - & 0.4 & $\mathrm{Tl}$ & - & - & - & - \\
\hline $\mathbf{U}$ & 0.2 & 1 & 0.1 & 0.1 & $\mathrm{Se}$ & - & - & - & - \\
\hline $\mathbf{V}$ & 40 & 25 & 177 & 134 & $\mathrm{Sc}$ & 15 & 7 & 41 & 32 \\
\hline $\mathbf{Z r}$ & 0.6 & 74.1 & 11.4 & 32 & $\mathrm{Y}$ & 0.5 & 31.1 & 10 & 20.1 \\
\hline
\end{tabular}

On the other hand, low Ti tholeiitic rocks from East Thessaly ophiolites (Migiros, 1986) exhibit a positive $\mathrm{Pb}$ anomaly, similar to that of lava, gabbro and rodingite sample respectively (Fig. 4b). They also present high Th values and negative Ti anomalies (Fig. 4b). Rodingite sample displays a high fractionation between the LREE and the HREE patterns (Fig. 4a). Its MREE and HREE patterns seem to be subparallel to those of gabbro and lava samples. It presents $(\mathrm{La} / \mathrm{Yb})_{\mathrm{N}}=8.59$ and 
$(\mathrm{La} / \mathrm{Sm})_{\mathrm{N}}=6.09$ (Fig. $\left.4 \mathrm{a}\right)$ and negative Eu anomaly $\left(\mathrm{Eu}_{\mathrm{N}} / \mathrm{Eu}^{*}=0.35\right)$. MORB normalized multi-trace element show a clear Ba and $\mathrm{Sr}$ enrichment and strong Ti, Sr, K negative anomalies, while their U, $\mathrm{Nb}$ and LREE values are quite high (Fig. 4b).
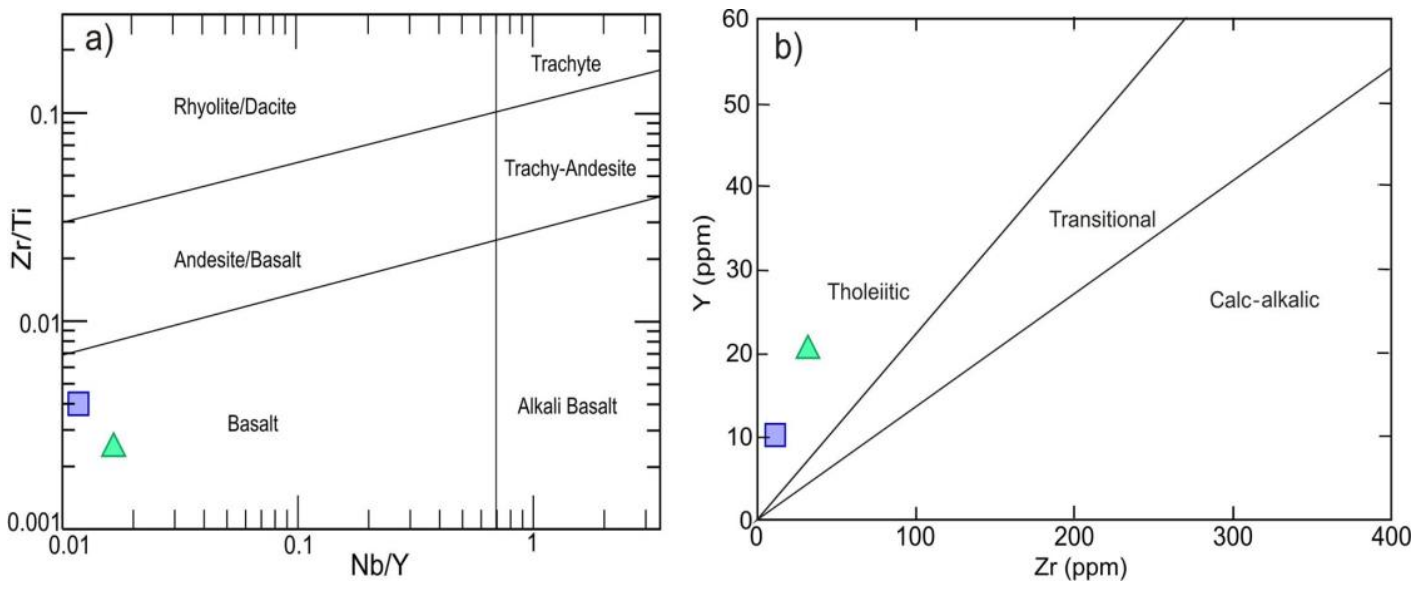

Figure 3 - a). Binary classification diagram of $\mathrm{Zr} / \mathrm{Ti}$ vs. Nb/Y (Winchester and Floyd, 1977, modified by Pearce 1996) for basaltic lava (triangle) and gabbro (square) samples. b). Y (ppm) vs Zr (ppm) magmatic affinity distinguishing diagram (Barrett and Maclean, 1999).
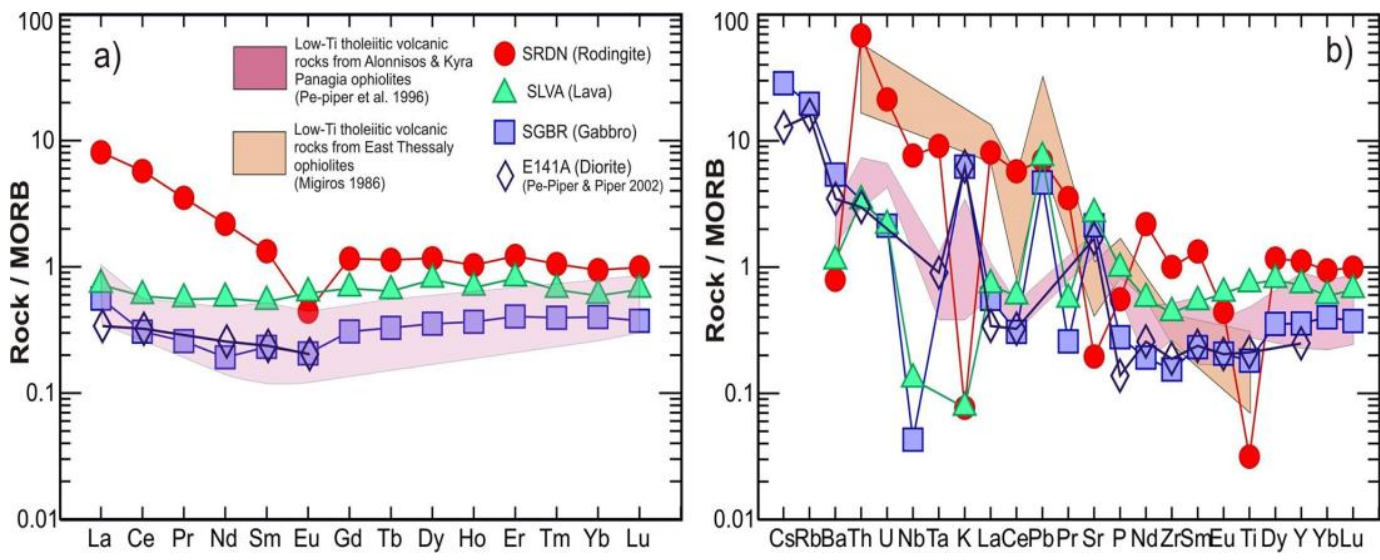

Figure 4 - MORB-normalized REE patterns [normalization factors after Pearce and Parkinson (1993)] of rodingite (SRDN), gabbro (SGBR), basaltic lava (SLVA) samples from Skyros. b)

MORB-normalized multi-trace element patterns. For comparison, diorite (E141A) is from Skyros (Pe-Piper and Piper, 2002), volcanic rocks from Kyra Panagia ophiolites (Pe-Piper et al., 1996) and volcanic rocks from E. Thessaly ophiolites (Migiros, 1986).

\section{Discussion}

\subsection{Metamorphic and metasomatic processes}

Ophiolites are often exposed to orogenic and/or oceanic metamorphism and metasomatism which may be associated with subduction and subsequent exhumation processes and also the hydrothermal fluids circulation (e.g. Manning and Bird, 1995; Magganas and Koutsovitis, 2015 and references therein). During the exhumation stage circulating subduction related fluids and/or oceanic thermal waters may alter the ophiolitic rocks. Serpentinization and rodingitization of the ultramafic and basic rocks respectively are two of the most usual alteration processes. The mineralogy of the Skyros ophiolitic rocks imply for an intense alteration, which due to the absence of strong or pervasive 
foliation in all magmatic rocks is assumed to have been developed mostly during oceanic metamorphism and metasomatism. In particular, the basaltic and gabbroic rocks have been subjected from medium to very low grade oceanic metamorphism (lower amphibolite to prehnite-pumpellyite facies), as noticed by clinopyroxene alteration, and the abundance of secondary minerals such as hornblende, albite, chlorite, epidote, prehnite and pumpellyite. Similarly, ultramafic rocks have been subjected to intense serpentinization, noticed by the predominance of serpentine (antigorite), but also by the replacement of pyroxenes to bastites and spinel alteration to magnetite. The presence of quartz and epidote-rich late veins within dolerite points also for alteration induced by low T oxidized silica-rich hydrothermal fluids. However, the role of subduction originated fluids to this alteration needs more data to be clearly evaluated for these rocks.

The formation of rodingite can be ascribed to intense metasomatic processes, either associated with sea but possibly also with subduction related fluids (e.g. Li et al., 2004; Tsikouras et al., 2009; Koutsovitis et al., 2013). The main rodingitization stages are interpreted by the Coleman reactions (1967) as seen below:

(1) $1.5 \mathrm{An}+0.5 \mathrm{Ca}^{+2}+1.5 \mathrm{H}_{2} \mathrm{O} \rightarrow \operatorname{Prh}+0.5 \mathrm{Al}_{2} \mathrm{O}_{3}+\mathrm{H}^{+}$,

(2) $\quad 2 \mathrm{Prh}+2 \mathrm{Ca}^{+2} \rightarrow 2 \mathrm{Hgrs}+\mathrm{Si}^{+4}$

(3) $\mathrm{An}+2 \mathrm{Ca}^{+2}+3 \mathrm{H}_{2} \mathrm{O}+0.5 \mathrm{SiO}_{2} \rightarrow 2 \mathrm{Hgrs}+4 \mathrm{H}^{+}$

Most garnets are hydroandradites, while there are some small sized $\mathrm{Cr}$-bearing hydrogarnets crystals $\left(\mathrm{Cr}_{2} \mathrm{O}_{3}=10.34 \mathrm{wt} . \%\right)$. Li et al. (2008) explains the formation of hydrogarnet with clinopyroxene and water participation in the reaction with plagioclase, whereas Cr-bearing hydrogarnets formation is related with $\mathrm{Cr}$ release from serpentinites ( $\mathrm{Li}$ et al., 2004). The vesuvianite was most likely formed in very low $\mathrm{CO}_{2}$ conditions with water rich fluids, at $300-400^{\circ} \mathrm{C}(\mathrm{Li}$ et al., 2004, Hatzipanagiotou et al., 2003, Li et al., 2008, Koutsovitis et al., 2013). Nevertheless, in a lower T stage and during the ophicalcite formation the chemistry of pore waters were enriched in $\mathrm{CO}_{2}$.

As the ophiolitic rocks clearly escaped any post-Cretaceous high pressure event of regional metamorphism, whereas their underlying metamorphosed rocks of the Eohellenic nappe were probably involved in it (presence of blueschist facies assemblages), the former can correspond to the analogous rocks of the upper tectonic unit (UTU) of the Attico-Cycladic Zone (e.g. those occur in Tinos Island) and the latter to the lower blueschist tectonic unit (BTU) of the Cyclades. In such case, we suggest provided the tectonic contact between Skyros ophiolitic rocks and underlying schists and marbles interpreted as a low-angle detachment zone, then it maybe represents part of the northward extension of the North Cycladic Detachment System (NCDS) (Jolivet et al., 2010).

\subsection{Geotectonic setting}

Based upon the geochemical data of the basalt and gabbro samples (Fig. 4), it is evident that these have been affected by subduction-related processes. This can be observed by the La/10-Y/15-Nb/8 ternary diagram (Fig. 5) in which the studied samples plot within the island arc settings field. On the other hand, the $\mathrm{Nb} / \mathrm{Th}$ ratio has been used by researchers (e.g. Pearce and Peate 1995; Koutsovitis, 2012) to characterize the tectonic settings of volcanic rocks, with the values lower than ' 4 ' characterizing arc-related rocks. Thus, the very low $\mathrm{Nb} / \mathrm{Th}$ ratios $(0.5-0.75)$ strongly suggests subduction processes, which are further confirmed by their slightly enriched $\mathrm{Th} / \mathrm{Yb}$ ratios $(0.17$ 0.23; for MORB 0.05, Pearce, 2008). Furthermore, the high MORB-normalized Th and U values compared to those of $\mathrm{Nb}$ for the gabbro and basalt samples (Fig. 4b), may account for influence of subduction processes (Pearce and Peate, 1995; Campbell, 2001).

Small negative $\mathrm{Zr}$ anomalies may be either related to subduction or may be attributed to source depletion. The observed positive $\mathrm{Pb}$ and $\mathrm{Sr}$ anomalies favor subduction; however, secondary processes most likely affected their original magmatic values. Crustal contamination processes most likely did not take place due to the tholeiitic affinity of the studied mafic rocks. On the other hand, the types of hydrogarnet and vesuvianite crystals found within the rodingites are indicative for the involvement of subduction-related fluids during the formation of the rodingites (Koutsovitis et al., 2013). In addition, the chemistry of spinels in serpentinites $\left(\mathrm{TiO}_{2}=0.14-0.25\right.$ wt. $\%, \mathrm{Al}_{2} \mathrm{O}_{3}=35.1$ - 
35.21 wt. $\%, \mathrm{Cr} \#=37.38-38.87)$, shows that their harzburgitic protoliths plausibly resemble back-arc basin peridotites (Kamenetsky et al., 2001). These implications seem to correspond to those of Skyros high $\mathrm{Mg}$ and $\mathrm{Al}$ chromitites whose petrological and geochemical features indicate a suprasubduction zone (SSZ)/back arc basin environment (Economou et al., 1999). Looking on the geochemistry of the ophiolitic volcanics of the Eohellenic nappe in other parts of east central Greece a general similarity is noted. In particular, the low-Ti tholeiitic volcanic rocks from Alonnisos and Kyra Panagia ophiolites (Pe-Piper et al., 1996) exhibit subparallel MORB-normalized multi-trace element patterns with our studied gabbro and basalt (Fig. 4b). Based upon their trace element and REE geochemistry the majority of Alonnisos and Kyra Panagia rocks formed in an arc related environment (Pe-Piper and Piper, 2002) which corresponds to Skyros subduction related geochemical features. Furthermore, low-Ti tholeiitic volcanic rocks from East Thessaly ophiolites (Migiros, 1986) present subparallel MORB-normalized patterns with Skyros rodingites, exhibiting Ti negative anomalies (Fig. 4b), which further confirm the assumption that Eohellenic nappe ophiolitic rocks from all North Sporades Islands and East Thessaly probably formed within the same supra-subduction zone geotectonic environment of the Jurassic - Lower Cretaceous Vardar Ocean. In addition, certain similarities in tectonic and stratigraphic position, petrogenetical evolution and metamorphism (up to greenschist facies) of these east-central Greece Eohellenic ophiolites and the ophiolitic rocks of the upper tectonic unit of the Attico-Cycladic Zone indicate that they may establish an elongated ophiolitic zone, which, hosting dispersed and small in volume ophiolitic complexes of Vardar Ocean origin, can be associated to the hanging wall of the northward extension of the North Cycladic Detachment System. However many more data are needed in order this hypothesis to be confirmed.

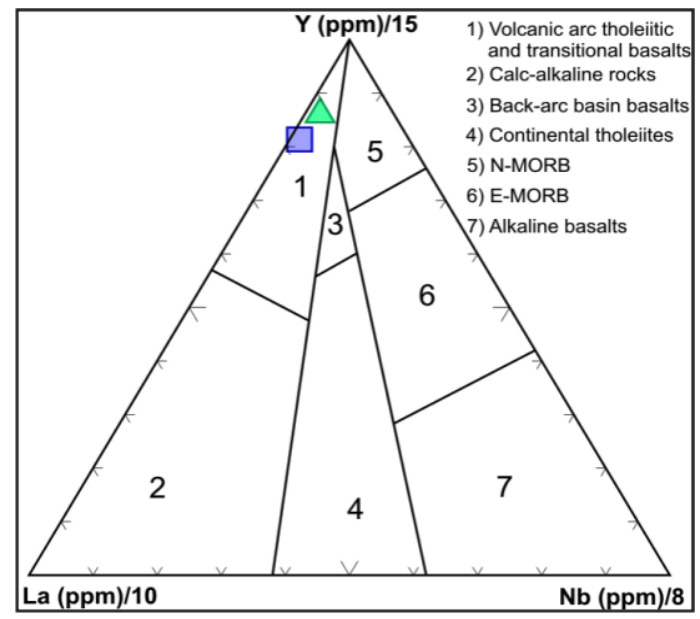

Figure 5 - Ternary diagram La/10-Y/15-Nb/8 for geotectonic environment discrimination of basaltic to felsic rocks (after Cabanis and Lecolle, 1989).

\section{Conclusions}

The studied rocks occurring on top of the Eohellenic nappe in Skyros mainly consists of serpentinized harzburgite, gabbroic rocks, dolerites, tholeiitic basalt and rodingite. Based on their mutual contacts, which mostly are tectonic and the co-occurrence of ophicalcite, lateritic ores and cherts these magmatic rocks constitute an ophiolitic mélange of probably Upper Jurassic - Lower Cretaceous age. The rocks of the mélange have been affected by low to moderate metamorphic and metasomatic processes; however, some of their magmatic features have been preserved, especially in gabbroic rocks and basalt. Their mineral chemistry as well as their whole rock chemistry suggests that these ophiolitic rocks are associated with subduction-related processes. The presence of vesuvianite crystals in rodingites, as well as the occurrence of relict spinels within serpentinitic rocks, further supports this assumption. Taking into account a geochemical and petrological comparison 
between Skyros ophiolitic rocks and similar rocks of the Eohellenic nappe in East Thessaly and other N. Sporades islands we suggest that they all share many petrogenetical and evolutionary features. On the other hand, a similar origin and evolution may exist and with analogous rocks occurring in the upper tectonic unit of the Attico-Cycladic Zone.

\section{References}

Baltatzis, E., 1984. A new occurrence of rodingite from Skiros island, Greece, N. Jb. Mineral. Mh., 317-322

Barrett, T.J. and MacLean, W.H., 1999. Volcanic sequences, lithogeochemistry, and hydrothermal alteration in some bimodal volcanic-associated massive sulfide systems, in Volcanic Associated Massive Sulfide Deposits: Processes and Examples in Modern and Ancient Environments, Society of Economic Geologists, Reviews in Economic Geology, 8, 101-131.

Beccaluva, L., Ohnestetter, D., Ohnestetter, M. and Paupy, A., 1984. Two magmatic series with island arc affinities within the Vourinos ophiolites, Contrib. Mineral. Petrol., 85, 253-271.

Cabanis, B. and Lecolle, M., 1989. The La/10-Y/15-Nb/8 diagram; a tool for distinguishing volcanic series and discovering crustal mixing and/or contamination, Comptes Rendus de l'Academie des Sciences, 309, 2023-2029 (in French with an English abstract).

Campbell, I.H., 2001. Identification of ancient mantle plumes. In: Ernst, R.E. and Buchan, K.L., eds., Mantle plumes: their identification through time, Geological Society of America Special Paper, 352, 5-21.

Coleman, R.G., 1967. Low-temperature reaction zones and alpine ultramafic rocks of California, Oregon and Washington, U.S. Geological Survey Bulletin, 1247, 1-49.

Economou-Eliopoulos, M. and Eliopoulos, D.G., 1999. Significance of a Spatial Association of High-Cr and High-Al Chromites for Their Genesis and Exploration, Extrait du Bulletin T. CXIX de l' Académie Serbe des Sciences et des Arts, Classe des Sciences mathématiques et naturelles, Science naturelles, 39, 123-140.

Ferrière, J., Chanier, F. and Ditbanjong, P., 2012. The Hellenic ophiolites: eastward or westward obduction of the Maliac Ocean, a discussion, International Journal of Earth Sciences, 101, 1559-1580.

Harder, H., Jacobshagen, V., Skala, W., Arafeh, M., Berndsen, J., Hofmann, A., Kusserow, H. and Schedler, W., 1983. Geologische Entwicklung und Struktur der Insel Skyros, Nordsporaden, Griechenland, Berliner geowissenschaftliche Abhandlungen, 48(A), 7-40.

Hatzipanagiotou, K., Tsikouras, B., Migiros, G., Gartzos, E. and Serelis, K., 2003. Origin of rodingites in ultramafic rocks from Lesvos island (NE Aegean, Greece), Ofioliti, 28, 13-23.

Heinitz, W., and Richter-Heinitz, I., 1983. Geologische Unteersuchungen im Nordost-Teil der Insel Skiathos (Griechenland), Berliner geowissenschaftliche Abhandlungen Berlin, 48(A), 41-63.

Jacobshagen, G. and Matarangas, D., 2004. Nappe structure of the North Sporades (Greece): on the geological evolution of Alonissos island, Bull. Geol. Soc. Greece, 36/4, 1636-1642.

Jolivet, L., Lecomte, E., Huet, B., Denele, Y., Lacombe, O., Labrousse, L., Le Pourhiet, L. and Mehlet, C., 2010. The North Cycladic Detachment System, Earth and Planetary Science Letters, 289, 87-104.

Kamenetsky, V.S., Crawford, A.J. and Meffre, S., 2001. Factors controlling chemistry of magmatic spinel: an empirical study of associated olivine, $\mathrm{Cr}$-spinel and melt inclusions from primitive rocks, Journal of Petrology, 42(4), 655-671.

Katsikatsos, G.H., 1992. Geology of Greece, Patra, University Publications, 451 pp.

Koutsovitis, P., 2012. Gabbroic rocks in ophiolitic occurrences from East Othris, Greece: petroge-netic processes and geotectonic environment implications, Mineralogy and Petrology, 104(3), 249-265.

Koutsovitis, P., Magganas, A., Pomonis, P. and Ntaflos, T., 2013. Subduction-related rodingites from East Othris, Greece: Mineral reactions and physicochemical conditions of formation, Lithos, 172-173, 139-157.

Li, X.P., Rahn, M. and Bucher, K., 2004. Metamorphic Processes in Rodingites of the Zermatt-Saas Ophiolites, International Geology Review, 46, 28-51. 
Li, X.P., Rahn, M. and Bucher, K., 2008. Eclogite facies metarodingites: phase relations in the system $\mathrm{SiO} 2-\mathrm{A} 12 \mathrm{O} 3-\mathrm{Fe} 2 \mathrm{O} 3-\mathrm{FeO}-\mathrm{MgO}-\mathrm{CaO}-\mathrm{CO} 2-\mathrm{H} 2 \mathrm{O}$ : an example from the ZermattSaas ophiolite, Journal of metamorphic Geology, 26, 347-364.

Manning, C.E. and Bird, D.K., 1995. Porosity, permeability and basalt metamorphism. In: Schiffman, P. and Day, H.W., eds., Geological Society of America Special Paper, 296, 123-140.

Matarangas, D., 1992. Geological investigations of Skopelos island (North Sporades, Greece), Berichte des Forschungszentrums Jülich, 2684, 157.

Magganas, A., 2002. Constraints on the petrogenesis of Evros ophiolite extrusives, NE Greece, Lithos, 65, 165-182.

Magganas, A. and Koutsovitis, P., 2015. Composition, melting and evolution of the upper mantle beneath the Jurassic Pindos ocean inferred by ophiolitic ultramafic rocks in East Othris, Greece, International Journal of Earth Sciences, 104, 1185-1207.

Migiros, G., 1986. The ophiolites of East Thessaly, IGME Geol. \& Geoph. Special Issue, Athens, 249-268.

Migiros, G. and Economou, G.S., 1988. Chromites in the ultrabasic rocks East Thessaly Complex (Central Greece), Ofioliti, 13, 127-136.

Papanikolaou, D., 2009. Timing of tectonic emplacement of the ophiolites and terrane paleogeography in the Hellenides, Lithos, 108, 262-280.

Pearce, J.A. and Parkinson, I.J., 1993. Trace element models for mantle melting: application to volcanic arc petrogenesis. In: Pichard, H.M., Alabaster, T., Harris, N.B.W., Neary, N.B.W., eds., Magmatic Processes and Plate Tectonics, Geol. Soc. London Sp. Pub., 76, 373-403.

Pearce, J.A., 1996. A user's guide to basalt discrimination diagrams. In: Wyman, D.A., ed., Trace element geochemistry of volcanic rocks: applications for massive sultide exploration, Geological Association of Canada, Short Course Notes, 12, 79-113.

Pearce, J.A. and Peate, D.W., 1995. Tectonic implications of the composition of volcanic ARC magmas, Annual Review of Earth and Planetary Sciences, 23, 251-285.

Pearce, J.A., 2008. Geochemical fingerprinting of oceanic basalts with applications to ophiolite classification and the search for Archean oceanic crust, Lithos, 100, 14-48.

Pelletier, L., Vils, F., Kalt, A. and Gméling, K., 2008. Li, B and Be Contents of Harzburgites from the Dramala Complex (Pindos Ophiolite, Greece): Evidence for a MOR-type Mantle in a Supra-subduction Zone Environment, Journal of Petrology, 49(11), 2043-2080.

Pe-Piper, G., Matarangas, D. and Jacobshagen, V., 1996. The Mesozoic metavolcanics rocks of Alonnisos and Kyra Panagia islands, Sporades, Greece, N. Jb. Miner. Mh, 6, 251-263.

Pe-Piper, G. and Piper, D.J.W., 2002. "The Igneous rocks of Greece: the anatomy of an orogen", Gebrüder Borntraeger, Stuttgart, 573 pp.

Pomonis, P., Tsikouras, B. and Hatzipanagiotou, K., 2007. Petrogenetic evolution of the Koziakas ophiolite complex (W. Thessaly, Greece), Mineralogy and Petrology, 89, 77-111.

Robertson, A.H.F., 2004. Development of concepts concerning the genesis and emplacement of Tethyan ophiolites in the Eastern Mediterranean and Oman regions, Earth-Science Reviews, 6, 331-387.

Saccani, E., Photiades, A. and Beccaluva, L., 2008. Petrogenesis and tectonic significance of Jurassic IAT magma-types in the Hellenide ophiolites as deduced from the Rhodiani ophiolites (Pelagonian zone, Greece), Lithos, 104, 71-84.

Stampfli, G.M., Vavassis, I., de Bono, A., Rosselet, F., Matti, B. and Bellini, M., 2003. Remnants of the Palaeotethys oceanic suture-zone in the western Tethyan area, Bolletino della Società Geologica Italiana, Volume speciale, 1-24.

Tsikouras, B., Karipi, S., Rigopoulos, I., Perraki, M., Pomonis, P. and Hatzipanagiotou, K., 2009. Geochemical processes and petrogenetic evolution of rodingite dykes in the ophiolite complex of Othrys (Central Greece), Lithos, 113, 540-554.

Whattam, S.A. and Stern, R.J., 2011. The 'subduction initiation rule': A key for linking ophiolites, intra-oceanic forearcs and subduction initiation, Contributions to Mineralogy and Petrology, 162, 1031-1045.

Winchester, J.A. and Floyd, P.A., 1977. Geochemical discrimination of different magma series and their differentiation products using immobile elements, Chem. Geol., 20, 325-343. 